\title{
A METHOD TO ESTIMATE DEPENDABLE RAINFALL IN MONTHLY, WEEKLY AND TEN DAY INTERVALS FOR SRI LANKA
}

\author{
K.D.N. WEERASINGHE \\ Department of Agronomy, Faculty of Agriculture, University of Ruhuna, Matara, Sri Lanka.
}

(Date of receipt : 20 November 1990)

(Date of acceptance : 05 March 1991)

\section{Introduction}

A rainfall probability analysis needs to be made from longterm rainfall records of at least 35 years for the assessment of rainfall availability for rainfed agriculture or irrigation water requirement. In rainfed agriculture one may be interested in dependable rainfall (how much rainfall can be expected in at least 3 out of 4 years). The dependable rainfall of $75 \%$ or $80 \%$ probability corresponding one out of four or five years is used for the design of irrigation system capacity. The significance of the dependable rainfall for planning crop strategies and its monthly estimates for a number of stations in Sri Lanka is described elsewhere. ${ }^{5}$ Nevertheless it is unfortunate that rainfall data in climatic summaries in many countries are seldom given as probabilities, but as arithmatic means.

It has been reported of the possibility to use linear regression models between monthly rainfall and the dependable rainfall in order to overcome this problem. ${ }^{4}$ Analogical regression models were incorporated in the water balance models such as 'CROPWAT' and 'IRCIS'.,3

The aim of the present work is to search for such a relationship for Sri Lanka, which may help to simulate rainfall probabilities for different periods; month, ten day intervals (decade) or week.

\section{Materials and Methods}

The daily rainfall of 21 rainfall stations in Dry, Wet and Intermediate zones of Sri Lanka, for more than 35 consecutive years $(1950$ - 1987) were used for the analysis (table 1). The rainfall probabilities for the selected time intervals were calculated by ranking order method using the program FIRST. ${ }^{6}$ A regression analysis was conducted using the computer model CHART. 
Table 1: Annual rainfall (1950-1987) and the respective agroecological zones of the selected stations

$\begin{array}{lcccc}\text { STATION } & \text { LONG } & \text { LAT } & \text { RAINFALL } & \begin{array}{c}\text { AGRO ECO. } \\ \text { ZONE* }\end{array} \\ & \mathbf{E} & \mathbf{N} & \mathbf{m m} & \\ \text { 1. ANURADHAPURA } & 80.38 & 8.35 & 1282 & \text { DL1 } \\ \text { 2. A PELESSA } & 80.90 & 6.15 & 1092 & \text { DL1 } \\ \text { 3. BADULLA } & 81.05 & 6.99 & 2384 & \text { IM1 } \\ \text { 4. BATTICALOA } & 81.70 & 7.72 & 1765 & \text { DL2 } \\ \text { 5. CHARLEY MOUNT } & 80.28 & 6.00 & 2761 & \text { WL4 } \\ \text { 6. COLOMBO } & 79.86 & 6.90 & 2345 & \text { WL4 } \\ \text { 7. DANDENIYA } & 80.39 & 6.00 & 1724 & \text { WL2 } \\ \text { 8. DENAGAMA } & 80.79 & 6.06 & 1903 & \text { IL1 } \\ \text { 9. HAMBANTOTA } & 81.13 & 6.12 & 1041 & \text { DL5 } \\ \text { 10. JAFFNA } & 80.02 & 9.65 & 1213 & \text { DL4 } \\ \text { 11. MAHA ILUPPALLAMA } & 80.47 & 8.12 & 1379 & \text { DL1 } \\ \text { 12. MANNAR } & 79.92 & 8.95 & 958 & \text { DL3 } \\ \text { 13. MAPALANA } & 80.57 & 6.07 & 2354 & \text { WL2 } \\ \text { 14. MAWARELLA } & 80.36 & 6.11 & 3067 & \text { WL1 } \\ \text { 15. NUWARA ELIYA } & 80.77 & 6.97 & 2328 & \text { WU3 } \\ \text { 16. POLONNARUWA } & 81.00 & 7.93 & 1669 & \text { DL1 } \\ \text { 17. PUTTALAM } & 79.83 & 8.03 & 1226 & \text { DL3 } \\ \text { 18. THIHAGODA } & 80.34 & 6.01 & 1830 & \text { WL4 } \\ \text { 19. TRINCOMALEE } & 81.21 & 8.58 & 1522 & \text { DL1 } \\ \text { 20. VAVUNIYA } & 80.50 & 8.75 & 1420 & \text { DL1 } \\ \text { 21. WATAWALA } & 80.60 & 6.95 & 5241 & \text { WU1 }\end{array}$

* Panabokke \& Walgama, 1974.

\section{Results and Discussion}

A highly significant correlation exists between monthly rainfall of $40>\mathrm{mm}$. and the $75 \%$ probable rainfall $(\mathrm{r}=0.91)$; This helped to suggest the following regression line for the estimation of dependable rainfall of the month (Figure 1).

$$
\mathrm{p} 75=0.693 \mathrm{pm}-26.263 \text { (for } \mathrm{Rf}>40 \mathrm{~mm} \text { ) }
$$

The above regression model agrees with the models established by Oldeman (1977) for Indonesia (p75 $=0.82 \mathrm{pm}-32$ ), Chaki and Neuwolt (1981) for Malaysia ( $\mathrm{p} 80=0.78 \mathrm{pm}-32)$, Hargreaves (1975) for thirteen south eastern states of the United States (p75 $=0.84 \mathrm{pm}-23)$, and Oldeman (1981) for Thailand $(\mathrm{p} 75=0.76 \mathrm{pm}-20){ }^{4}$

The correlation between the monthly rainfall below $40 \mathrm{~cm}$ and the depend- 
Figure 1

\section{RELATIONSHIP BETWEEN DEPENDABLE PRECIPITATION AND MONTHLY RAINFALL $>40 \mathrm{~mm}$.}

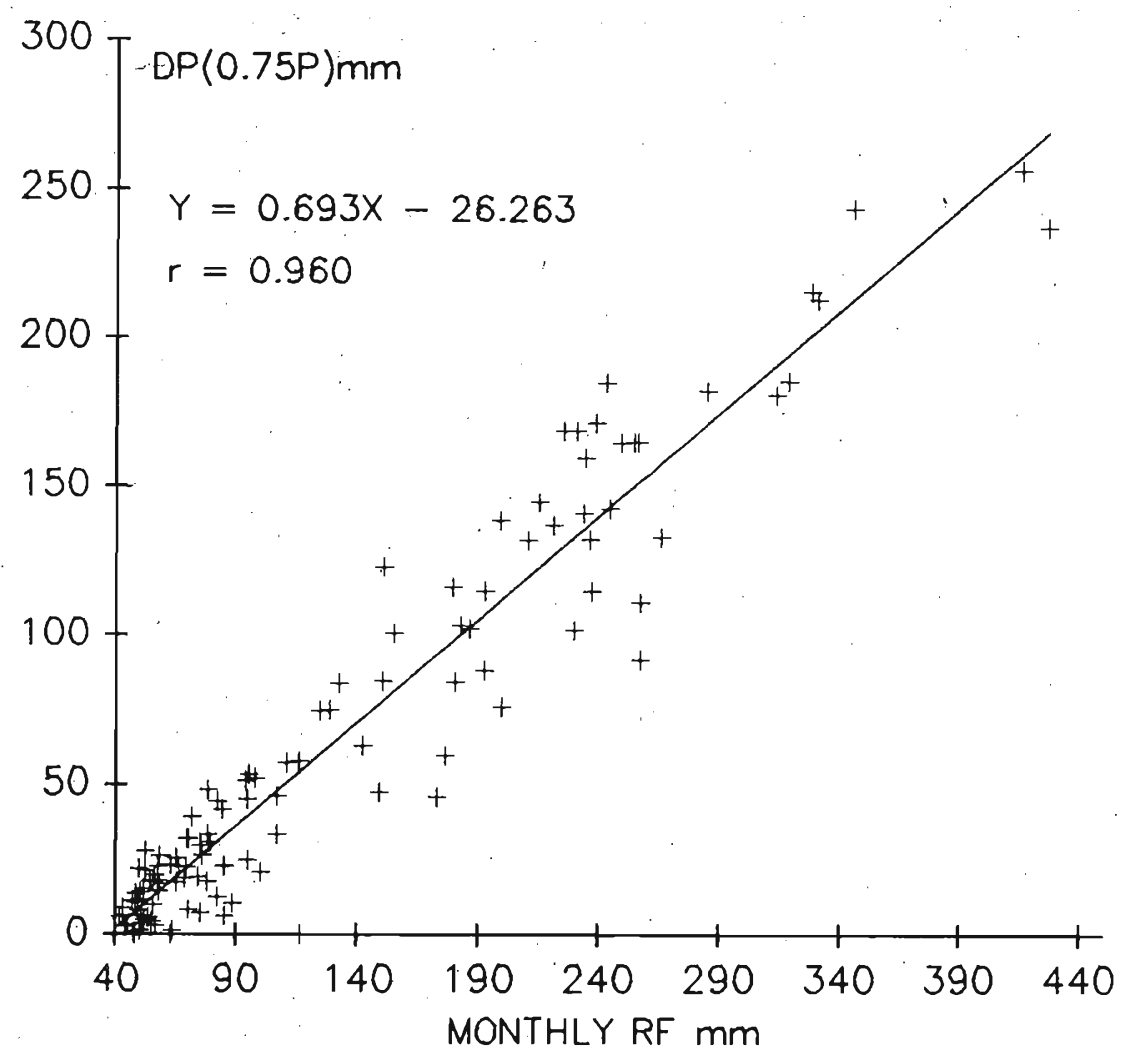

able precipitation appeared to be low $(\mathrm{r}=0.61)$ compared to rainfall $>40 \mathrm{~mm}$. (Figure 2). Following relationship would be valid for the monthly rain of $<40$ $\mathrm{mm}$;

$$
\mathrm{p} 75=0.245 \mathrm{pm}-1.38 \text { (for } \mathrm{Rf}<40 \mathrm{~mm})
$$

Analogically a highly significant linear relationship exists between mean rainfall of weekly and ten-day intervals with the dependable rainfall $(r=0.852$ and 0.885 for the weekly and ten-day rainfall $>15 \mathrm{~mm}$ and $>18 \mathrm{~mm}$. respectively). (Figures 3,5).

Nevertheless in respect to the lower rainfall limits the relationship appeared to follow a well pronounced exponentiality (Figures 4,6). Thus the following exponential equations seems to have a better validity for the assessment of dependable rainfall of the week and ten day periods. 
Figure 2

RELATIONSHIP BETWEEN DEPENDABLE PRECIPITATION AND MONTHLY RAINFALL $<40 \mathrm{~mm}$.

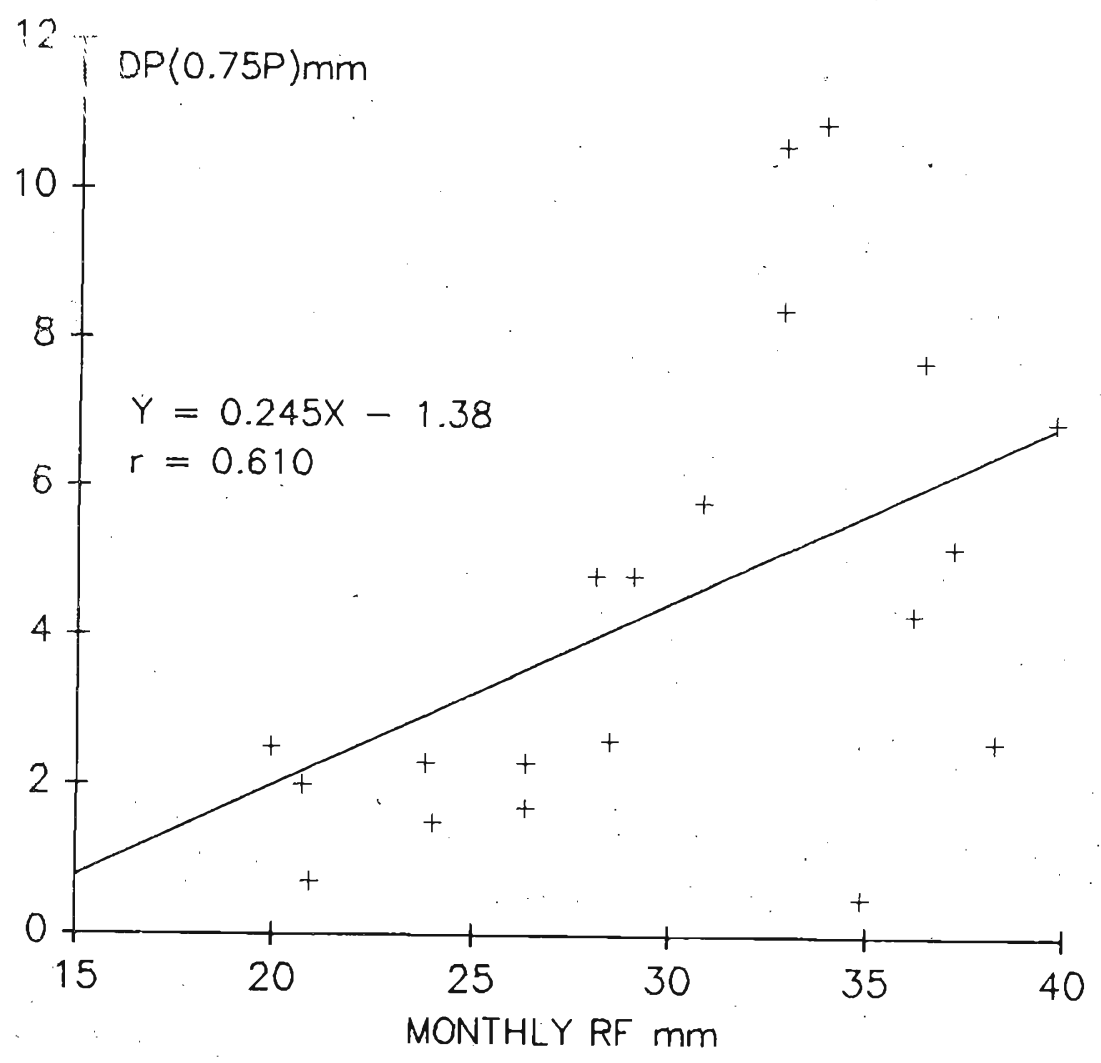


Figure 3

RELATIONSHIP BETWEEN TENDAY RAINFALL $>18 \mathrm{~mm}$ AND DEPENDABLE PRECIPITATION

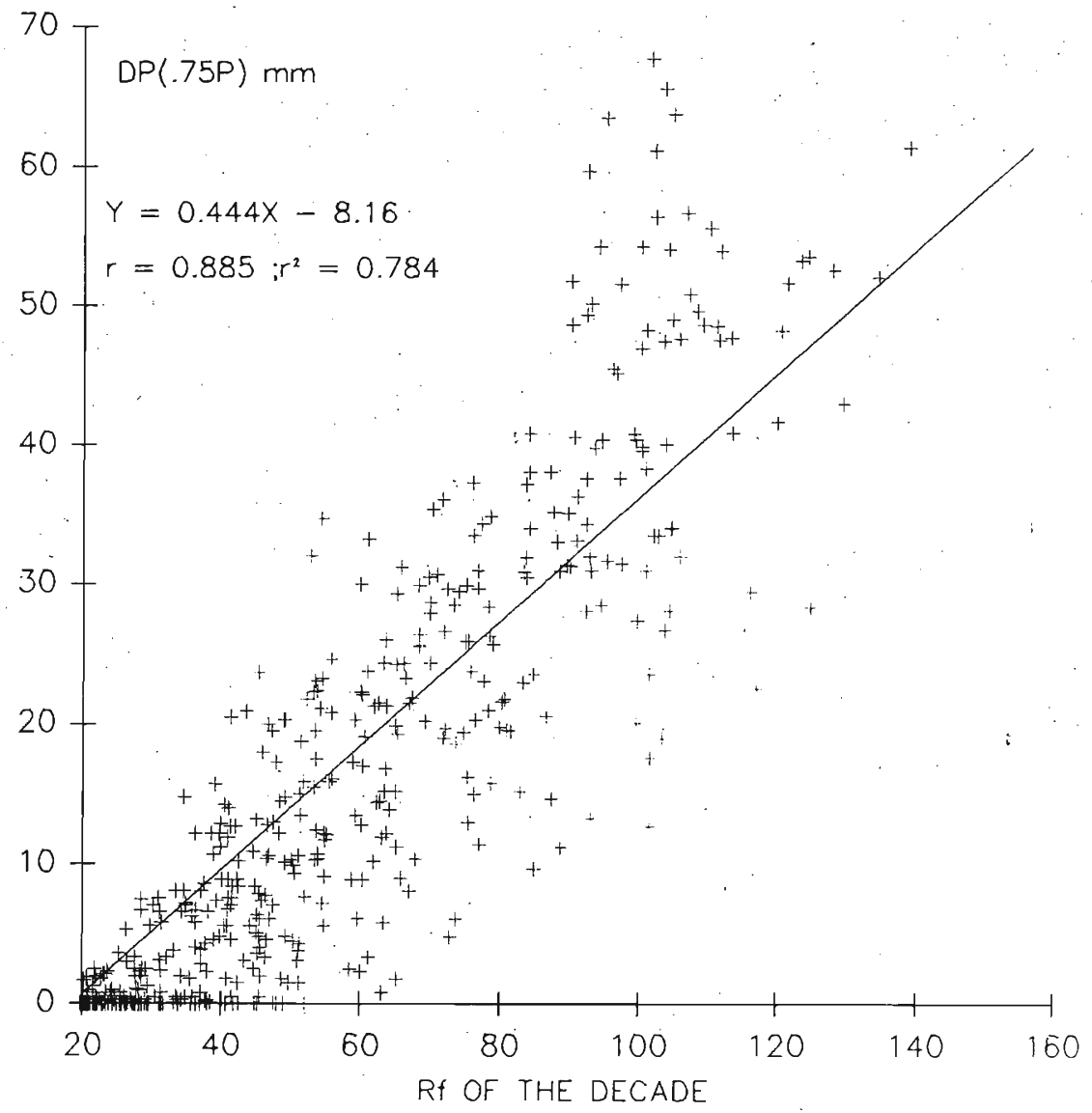


Figure 4

RELATIONSHIP BETWEEN TENDAY RAINFALL AND DEPENDABLE PRECIPITATION

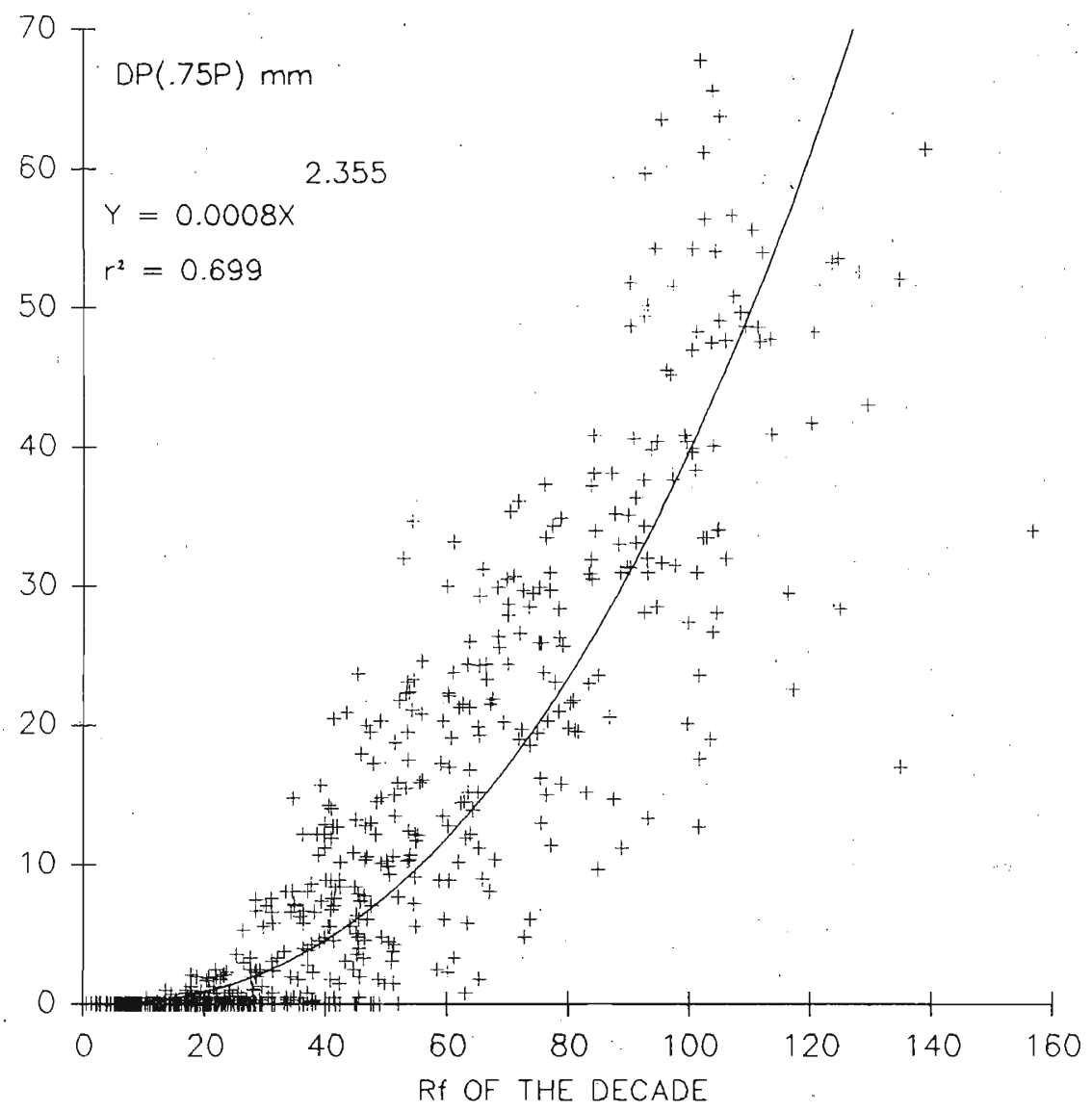


Figure 5

RELATIONSHIP BETWEEN WEEKLY RAINFALL $>15 \mathrm{~mm}$ AND DEPENDABLE PRECIPITATION (SRI LANKA)

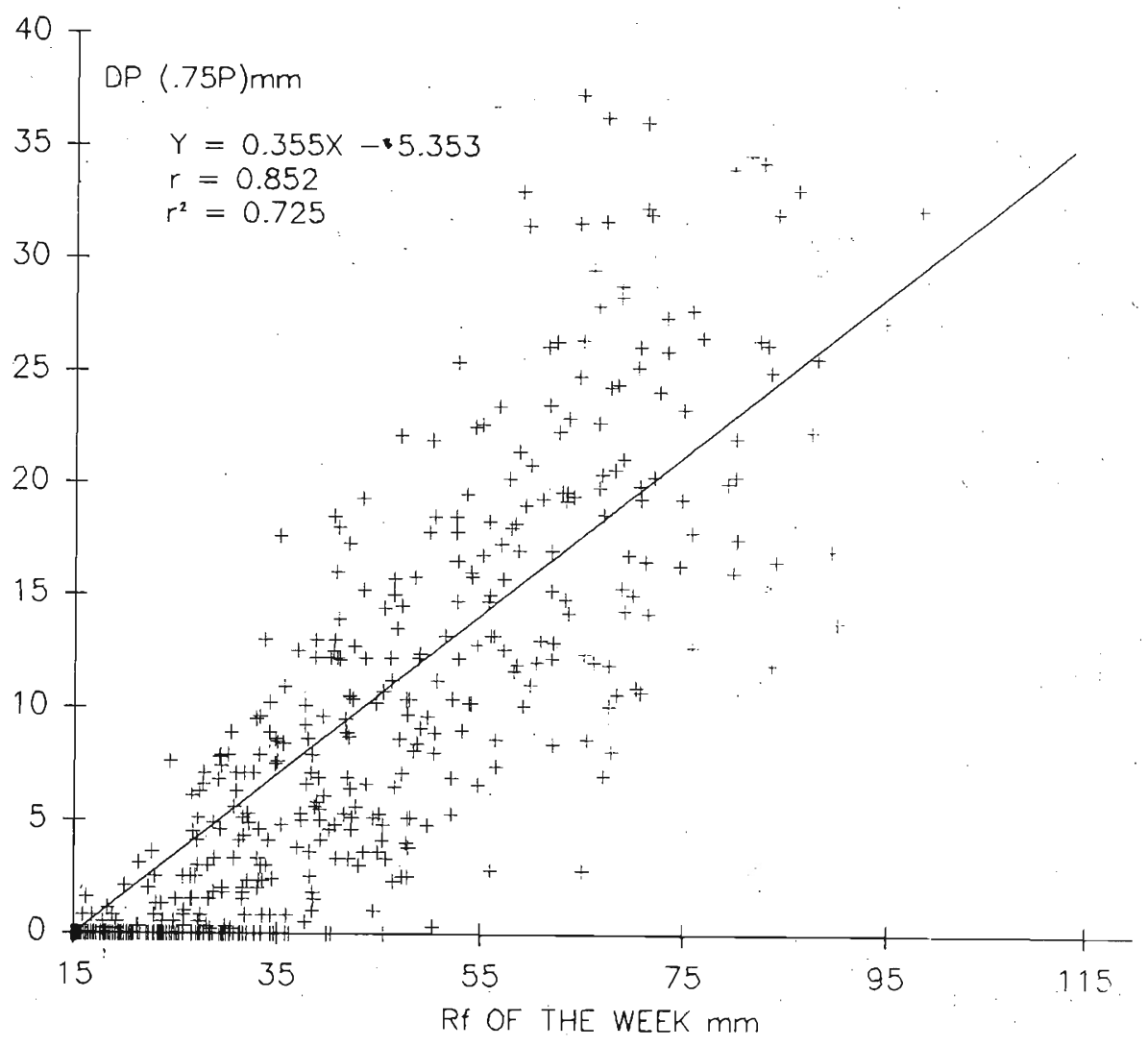


Figure 6

RELATIONSHIP BETWEEN DEPENDABLE PRECIPITATION AND WEEKLY RAINF ALL (SRI LANKA)

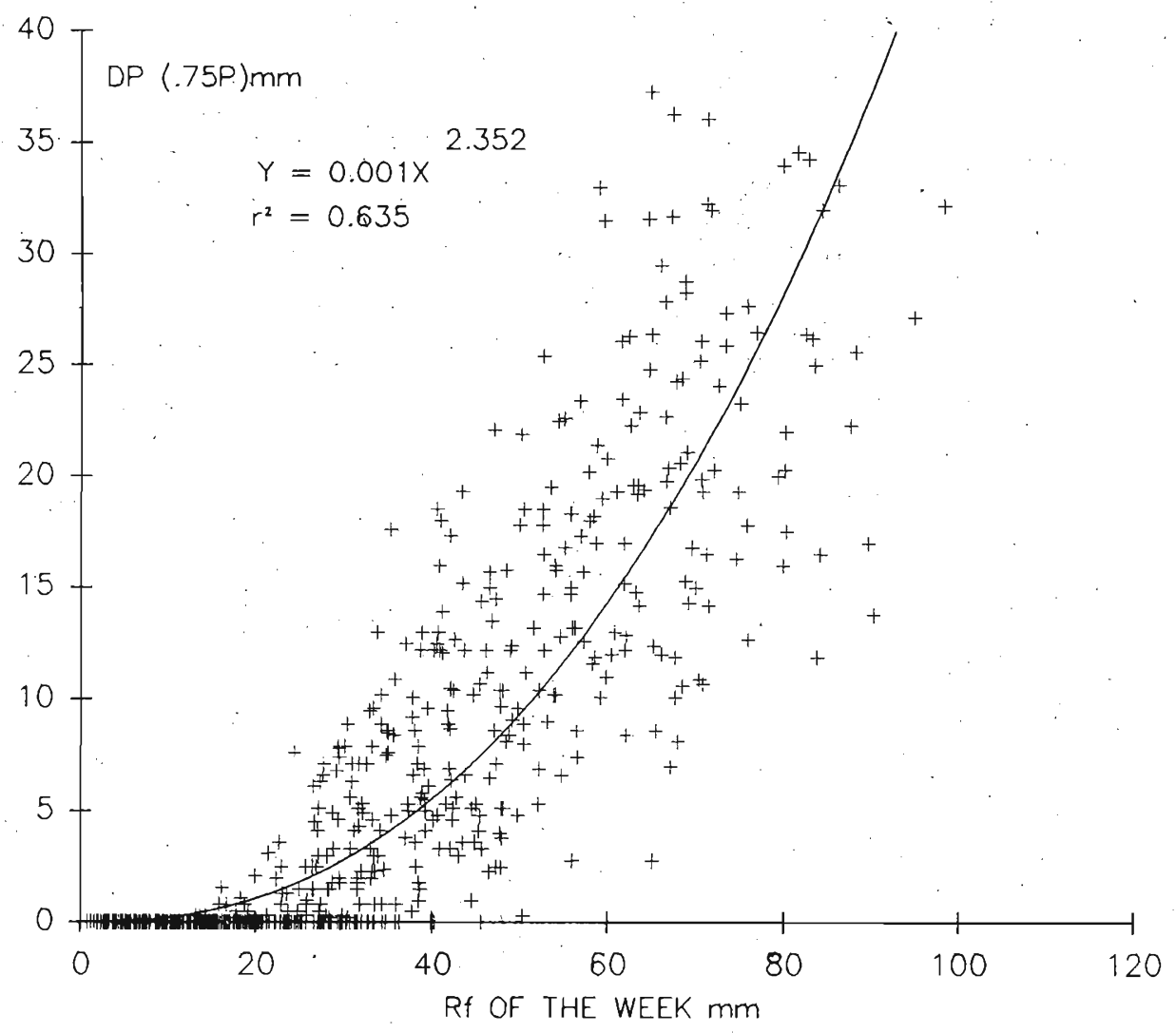




$$
\begin{array}{ll}
\text { p75 (wk })=0.001 \mathrm{X}^{2.352} & (\mathrm{X}=\text { rainfall of the week }) \\
\text { p75 }(\mathrm{TD})=0.008 \mathrm{X}^{2.355} & (\mathrm{X}=\text { rainfall for the ten-day period })
\end{array}
$$

It is clear that the dependable rainfall of the week and ten-day intervals approaches zero when the average rainfall of the period is $<20 \mathrm{~mm}$. As such the suggested linear regression equations may be used with fair accuracy for the computation of dependable rainfall in weekly or ten day intervals.

\section{Acknowledgements}

The author acknowledges the assistance provided by Dr. J. L. Sabatier (IRAT/CIRAD); Dr. M. Milliville (ORSTOM), Montpellier France and the Meteorological Department for the use of the rainfall files of the Department.

\section{References}

1. DOORENBOS, J. \& PRUITT, W. O. (1977) Crop water requirements, FAO Irri. and Drainage paper No. 24, FAO, Rome, 144.

2. IRSIS (1987) Irrigation sheduling information system based on the FAO Irrigation management model. Katholieke Universiteit Leuven Belgium.

3. MARTIN SMITH (1988) Manual for cropwat; A computer program for IBM-PC or compatibales FAO, Rome, 16-18.

4. OLDEMAN, L.R. \& FRERE, M. (1982) A study of Agroclimatology of the Humid tropics of South East Asia. WMO paper No. 597. Geneva. 143-160.

5. PANAB, KKE, C.R. \& WALGAMA, A. (1974) J. Natn. Sci. Coun. Sri Lanka 2 (2). 85-113.

6. WEERASINGHE, K.D.N., SABATIER, J.L. \& GRAND JEAN LUC. (1989) Mannual for "First". A computer program for Agroclimatological Data Analysis (unpublished report) IRAT/CIRAD. Montpellier France. 